\title{
An Empirical Assessment Of The EFQM Excellence Model In Purchasing
}

\author{
David Hems worth, Nipissing University, Canada
}

\begin{abstract}
This study focuses on the important concepts of quality management, internal customer satisfaction, and business performance within the neglected purchasing unit of manufacturing firms on the basis of the European Foundation for Quality Management (EFQM) Excellence Model, thus, filling a void in the existing literature. In doing so, this study tests the viability of the EFQM model in a single functional unit. Three hypothesis were generated based on the EFQM model to identify the specific relationships between purchasing's quality management practices (EFQM enabler), internal customer satisfaction, and business performance (EFQM results). The hypotheses were tested through structural equation modeling based on a sample of 306 purchasing agents within manufacturing. The results indicated that the EFQM seem to be a viable model that represents what impacts implementing QMP enablers will have on the resultants, ICS and OP. Additionally, the results identified that the extent of adoption of quality management purchasing has a direct positive impact on improving internal customer satisfaction and an indirect positive impact on business performance mediated by internal customer satisfaction, as predicted by the EFQM model. This study highlights the positive impact of adoption of EFQM in the purchasing area, thus, lends support to purchasing departments trying to justify the implementation of quality management practices to their administrations. Additionally, it gives upper management, looking for ways to improve the company's bottom line, the specifics to do this through the implementation of quality management practices in purchasing. Management and purchasing departments are given a blueprint for improving their performance.
\end{abstract}

Keywor ds: Purchasing; Quality Management; Supply Chain Management; Internal Customer Satisfaction; Business Performance; EFQM Model

\section{INTRODUCTION}

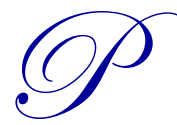

ressure on companies to remain profitable in an increasingly complex and competitive global marketplace has attracted managers' attention to supply chain management (SCM). Several authors have argued that the scope of SCM goes beyond the concept of integrated logistics and combines all business processes (Cooper, Lambert, \& Pagh, 1997), including quality management (Foster, 2008; Romano \& Vinelli, 2001; Talib, Rahman, \& Qureshi, 2011), customer relationship management, or, product development and commercialization (D. M. Lambert \& Cooper, 2000). To improve companies' competitiveness and efficiencies, numerous frameworks have been proposed (e.g., Malcolm Baldrige National Quality Award (MBNQA) and the European Foundation for Quality Management (EFQM) Excellence Model) to help integrate and improve quality management in firms and their supply chain at the company-wide (macro) level (Bou-Llusar, Escrig-Tena, Roca-Puig, \& Beltrán-Martín, 2009). This study applies one of these frameworks, the EFQM model specifically, to the purchas ing function (micro) of a company's supply chain.

An effective purchasing function has been considered a key business process in the supply chain (Fawcett \& Fawcett, 1995; Giunipero \& Brand, 1996; D. Lambert, Cooper, \& Pagh, 1998; Sánchez-Rodríguez \& Hems worth, 2005). Purchasing's role is very important as an intermediary in the supply chain, connecting suppliers with purchasing's internal customers who, in turn, provide products and services for the firm's external customers (D. R. Krause, Vachon, \& Klassen, 2009; Stanley \& Wisner, 2001). Because internal customers play an important role within the supply chain, internal customer satisfaction can also affect organizational performance (Panigyrakis \& Theodoridis, 2009; Yu, Qiu, \& Feng, 2010). The importance of internal customer satisfaction for a successful purchasing function has also been recognized in the recent literature (Large \& König, 2009; van Mossel\& van der Valk, 2008). Despite the numerous quality frameworks that have been proposed, adopted, and implemented, researchers (e.g., Bou-Llusar 
et al., 2009; Mcadam \& Leonard, 2005) have pointed out that there is a paucity of studies examining the effectiveness of these quality models (e.g., EFQM). Although the importance of purchasing and quality management to supply chain success is well known, to date there has been relatively little research regarding quality management practices in purchasing and their effect on internal customer satisfaction and business performance (Brandon-Jones \& Silvestro, 2010; Jun \& Cai, 2010; Panigyrakis \& Theodoridis, 2009). Therefore, the objectives of this paper represent a unique attempt to measure the EFQM model's viability, not to the company as a whole but as applied to a specific function al area, purchasing, due to its strategic importance and value creating nature (Björklund, 2010; Kern, Moser, Hartmann, \& Moder, 2012). Additionally, this research empirically examines the EFQM framework by relating the enablers quality management practices in purchasing - with the results - internal customer satisfaction and the organization's performance measures - all in the purchasing context.

Thus, in this paper the relevant SCM, TQM, purchasing, and EFQM literature is reviewed and associated hypotheses, derived from the EFQM framework, were developed and tested by means of structural equation modeling. The findings extend the understanding of the EFQM model's application to quality management practices in purchasing and the purchasing function's importance to the organization.

\section{LITERATURE REVIEW}

\subsection{TQM Impact on SCM and Operational Performance}

The impact of total quality management has been a prominent area of study in SCM. For example, Kuei, Madu, and Lin (2001) concluded that improvements in quality management practices in a supply chain are associated with improvements in organizational performance. Tan, Kannan, Handfield, and Ghosh (1999) examined the impact of TQM, supply base management, and customer relations practices on corporate performance. They concluded that performance improvement is more likely to happen if the company's quality and procurement implementation strategies are congruent with strategies in other business areas such as finance, operations, marketing, new product development, and sales. Salvador, Forza, Rungtusanatham, and Choi (2001) collected data from 164 plants to research whether an organization's interaction with its supply chain partners (suppliers and customers) to manage materials flow and ensure materials quality can improve time-related performance. One of the study's conclusions was that interactions with suppliers for quality management have a positive impact on delivery and operations performance. In a study of Thailand's automotive industry, Vanichchinchai and Igel (2011) identified a positive relationship between TQM and SCM, where TQM practices have a significant direct positive impact on SCM practices and supply performance. It has also been noted that supply chain management and quality management are correlated and positively associated with performance (Kannan \& Tan, 2005). Although most studies have identified a positive association between TQM and SCM (e.g., Hsu, Tan, Kannan, \& Leong, 2009; Theodorakioglou, Gotzamani, \& Tsiolvas, 2006), a recent study by Hsu et al. (2009) on the basis of 455 senior purchasing and operations managers identified a non-significant relationship between TQM capability and SCM practices, where supply chain management practices mediate the impact of operations capability on performance. This study also suggested that quality capability affects firm performance directly. Thus, either directly or indirectly through SCM, research has demonstrated that quality practice implementations can have an impact on firm performance.

\subsection{TQM in Purchasing}

Arguments for the relationship between quality management in purchasing and performance can be found in the resource-based view of the firm (J. Barney, 1991; J. B. Barney, 1986; Peteraf, 1993). According to this view, a firm can attain a competitive advantage by applying resources and capabilities at the firm's dis posal. According to Makadok (2001) "resources are stocks of available factors that are owned or controlled by the organization, and capabilities are an organization's capacity to deploy resources" (Amit \& Schoemaker, 1993, p.35). In simple terms it is the bundling of the resources that builds capabilities. As such, quality management could be considered more as a capability rather than a resource.

Giunipero and Vogt (1997) collected data from 85 purchasing managers and analyzed the commitment to empowerment, adoption of TQM and continuous improvement techniques, and the use of different types of teams in the purchasing function. One of the main conclusions of this study was that purchasing can play a key role in employee 
empowerment and TQM implementation. Additionally, empirical research in TQM has shown that cross -functional coordination and management commitment are positively correlated with quality performance and service quality (S Curkovic, Vickery, \& Droge, 2000; Hemsworth, Sánchez-Rodríguez, \& Bidgood, 2008; Yu et al., 2010), and that company performance is positively correlated with personnel management (Carter, Smeltzer, \& Narasimhan, 2000; Foster, 2008). Brookshaw and Terziovski (1997) described how "a clearly understood purchasing strategy in alignment with an organization-wide TQM culture and business strategy is expected to intensify the overall delivery of value to the customer" (p. 257). However, as the same authors pointed out, the empirical evidence is minimal. In their work they found significant differences in increased customer satisfaction between companies that had implemented quality-oriented purchasing and those that had not. However, as the same authors pointed out, the scale used to measure the construct of quality-oriented purchasing had limited reliability. In contrast, Caddick and Dale (1998) did not find evidence of a revised role of purchasing in a TQM environment. However, their findings suffered from a lack of scope since they reported empirical evidence from only a sing le case study.

Studies by Stanley and Wisner (1998; 2001; 2002) and Wisner and Stanley (1999) evaluated the implementation of purchasing activities and cooperative supplier relationships as sociated with high levels of internal and external quality service (customer satisfaction). Their main conclusion_ENREF_106_ENREF_124was that the purchasing function plays a key role in the integration and communication of quality expectations and the achievement of better quality performance. Purchasing's implementation of supplier quality management has been found to lower materials costs, increase quality of materials, reduce delays in deliveries from suppliers, and eliminate mistakes in quantities ordered and received (Anderson, Rungtusanatham, Schroeder, \& Devaraj, 1995; Kaynak, 2003; Lamming, 1993; Noordewier, George, \& Nevin, 1990; Vonderembse \& Tracey, 1999; Watts \& Hahn, 1993). However, the successful implementation of supplier quality management is preceded by the existence of an effective quality information system (Hemsworth et al., 2008; D. Krause, 1999; Lascelles \& Dale, 1989). The literature has also suggested that the purchasing function's ability to provide the optimum service to its internal customers is influenced by suppliers' performance levels (Large \& König, 2009; Stanley \& Wisner, 2001; Wisner \& Stanley, 1999). More recently, studies by Sánchez-Rodríguez and Hemsworth (2005) and Harsasi and Radhi (2010) identified a significant positive relationship between quality management practices in purchasing and purchasing performance. Thus, there is building support in the literature for the fact that quality management practice implantations result in an increase in purchas ing performance

\subsection{TQM's Impact on Internal Customer Satisfaction and Operational Performance}

A recent study by Vanichchinchai and Igel (2009) on TQM and SCM indicated that although TQM has an internal focus while SCM has an external focus, they both share the common goal of customer satisfaction. While TQM's focus is internal, the bulk of the literature attends to external as opposed to internal customer satisfaction (Stanley \& Wisner, 2001). As such "there is a need to emphasize both internal and external partnerships to further strengthen the emphasis on "total" TQM and the entire supply chain in SCM" (Vanichchinchai and Igel, 2009, p. 249). In addition, a study by Fredendall, Hopkins, and Bhonsle (2005) highlights the importance of internal customer satisfaction by noting that through both internal and external customers, organizations can 'understand the firm's requirements and effectively communicate these requirements to the supplier" (p. 26). Studies by Hult, Ferrell, Hurley, and Giunipero (2000) and Pfau, Detzel, and Geller (1991) suggest that organizational orientation toward internal customers is linked to external customer satisfaction. Furthermore, internal customer orientation leads to improved performance, supply chain management, and external and internal marketing Mohrw-Jackson, 1991; Panigyrakis and Theodoridis, 2009; Yu et al., 2010). On achieving internal customer satisfaction, it has been noted that internal service quality leads to internal customer satisfaction (Jun \& Cai, 2010). In addition, quality management practices in purchasing are associated with purchasing's operational performance and internal customer satisfaction (Sánchez-Rodríguez, Hemsworth, \& Martínez-Lorente, 2004). However, these studies failed to test the effect of quality management practices in purchasing on the people who the purchasing function serves and the resulting impact this has on the firm's performance.

\subsection{TQM and the Evolution of EFQM}

An important evolution of TQM adoption is the introduction of systematic approaches to quality management such as the quality awards including the Deming Prize (DP Model) in Japan, the Malcolm Baldrige National Quality Award 
(MBNQA) Model in the USA, and the European Quality Award (EFQM Excellence Model) as well as the criteria for company self-assessment (Ojanen, Piippo, \& Tuominen, 2002). The TQM principles and their impact on different aspects of the firm are the pillars on which the models of excellence rest. They also serve as the foundation on which companies have established a philosophy of managing for success in the long term and a strategy to improve performance. However, there has been only limited work that empirically examines the impact of models on companies (e.g., Bou-Llusar et al., 2009; S. Curkovic, Shawnee, \& Droge, 2000). Thus, more research must be conducted to understand the full implications these models can have on improving quality management implementations and to determine whether these models can be applied to individual business functions within the firm.

In 1988, the European commission prompted the creation of a non-profit and membership-based organization called the European Foundation for Quality Management (EFQM) whose aim was to come up with a representation of TQM theory that is implementable in all types of organizations. The resulting EFQM model (see Figure 1) is an advanced tool for organizational improvement inspired by the principles of Total Quality Management (TQM). In fact, agents in the EFQM model coincide with many of the elements included by different authors as critical factors in TQM (Flynn, Sakakibara, \& Schroeder, 1994; Saraph, Benson, \& Schroeder, 1989; Svensson \& Klefsjo, 2000). This model is based on managing the organization through a set of interdependent and interrelated systems, processes, and facts. It is a non-prescriptive management framework that is widely used by over 30,000 public and private sector organizations in the world. It can be used to gain a holis tic overview of any organization and helps managers to identify the main aspect to be improved for attaining excellence (Zink, 1995).

Figure 1. EQFM Model

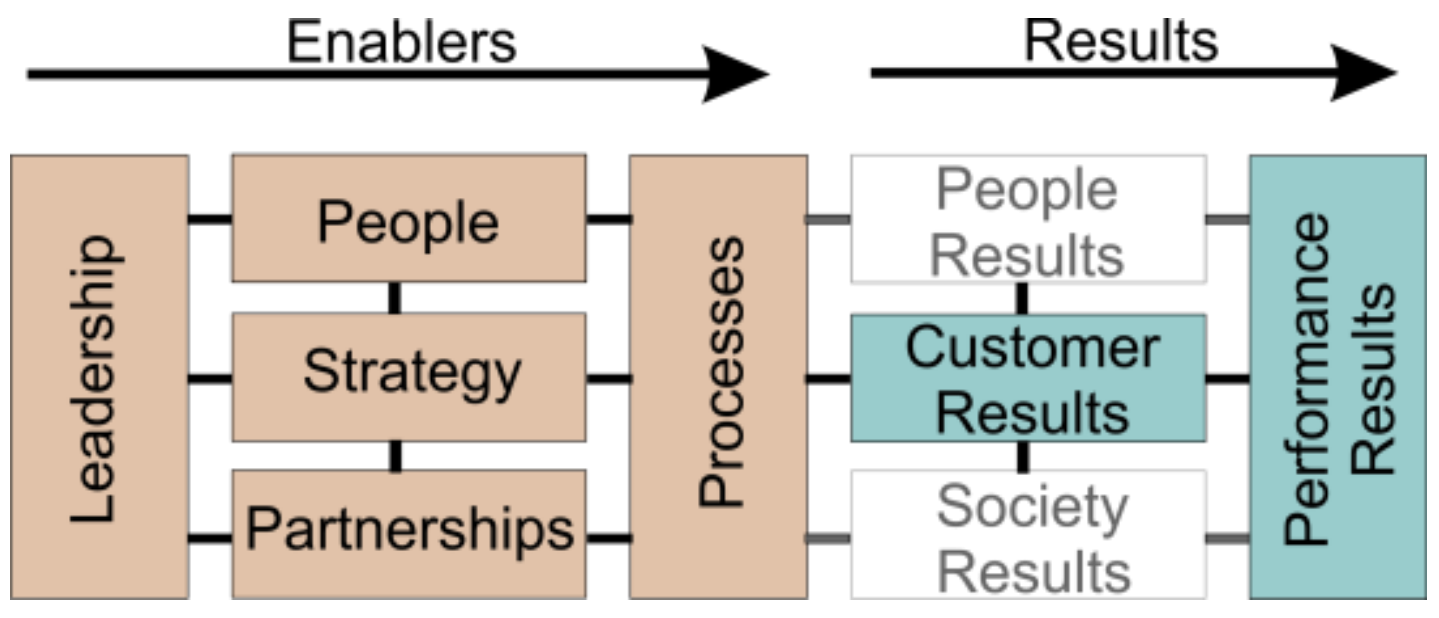

The EFQM model is composed of two major components: enablers and results. The enabler components include what an organization does in order to achieve excellence and involve five dimensions: leadership, people, strategy, resources, and processes (see Appendix 1 for details). All five enabler components are examined in this paper. The results aspect is composed of four firm-beneficial outcomes: people, customer, society, and performance (only the customer and performance results are examined here, society and people results were beyond the scope of the dataset). Some empirical work supports the existence of interrelationships among the enabler criteria of the model (Bou-Llusar, Escrig-Tena, Roca-Puig, \& Beltrán-Martín, 2005) showing that each are linked together in a very complex structure that makes it very difficult to discern each separately. According to this interpretation of the enabler side of the EFQM model, changes in one dimension are related to changes in other dimensions, and there is therefore a reciprocal interdependence between all enabler components.

A review of the literature quickly uncovers a large volume of studies on applying this model within various contexts (e.g., Hides, Davies, \& Jackson, 2004; Samuelsson \& Nilsson, 2002; Shaw, 2000; Wongrassamee, Simmons, \& Gardiner, 2003). These studies have a holistic macro approach to quality management and focus on organizationalwide application of the EFQM model. An exception applies to a few studies that focus on the application of an EFQM 
model within a section or department of an organization. For example, research conducted by Sanchez-Rodriguez, Martinez-Lorente, and Hemsworth (2012) focused on the impact of the EFQM model on adoption of e-procurement and performance. Other studies integrate the EFQM model and information systems (Sadeh, Arumugam, \& Malarvizhi, 2013) and customer-relationship-management systems (Reihanifard, Aminilari, Moghadam, Vahdat, \& Mozaffari, 2012) among SMEs. Another study focuses on application and assessment of customer focus based on the EFQM model within a local government (Jacobs \& Suckling, 2007).

Much of the literature has focused on the impact of individual criteria or linkages and does not allow for an assess ment of the entire set of EQFM enablers on the model's resultants (Bou-Llusar et al., 2009). Thus, this paper contributes by examining: 1) the micro application (opposed to the traditional macro/organizational level) of the EFQM model to a specific functional area (i.e., purchasing), by operationalizing the five EFQM enablers of quality management (i.e., personnel management, cross-functional co-ordination, and strategic purchasing) and resultant factors (internal customer satisfaction and business's performance) to the purchasing domain, 2) on the basis of testing the EFQM model, the impact of the enabler factors (quality management practices in purchasing) on the resultant factors internal customer satisfaction and performance. Consequently, this paper allows us to as sess the viability of using the EFQM framework to guide the implementation of contemporary quality management practices in purchasing (EFQM - enablers), and determining their impact on internal customer satisfaction (EFQM - result) and performance (EFQM - result) as well as demonstrating the micro (functional) application of the EFQM model.

\section{THEORETICAL FRAMEWORK AND HYPOTHESES}

Figure 2 presents the theoretical framework for the operationalization of the EFQM model (Figure 1) to the purchas ing function. This model forms the basis for this research study. The EFQM enablers (left side of the EFQM model in Figure 1) are represented in Figure 2 by the contemporary implementation of the quality management practices in purchasing (see Table 1 for details). The EFQM results pertaining to customers (middle section of Figure 1) are represented in Figure 2 by the measurement of the purchasing department's internal customers' satisfaction. The EFQM final performance results (right-most side of Figure 1) are represented by Figure 2's business performance results. Note that only the shaded areas in Figure 1, excluding the EFQM results pertaining to the personnel and society (these are beyond the scope of the current study), are tested in the model presented in Figure 2.

Figure 2. Theoretical Framework - Operationalization of the EFQM model for the purchasing function

\section{Enablers Results}

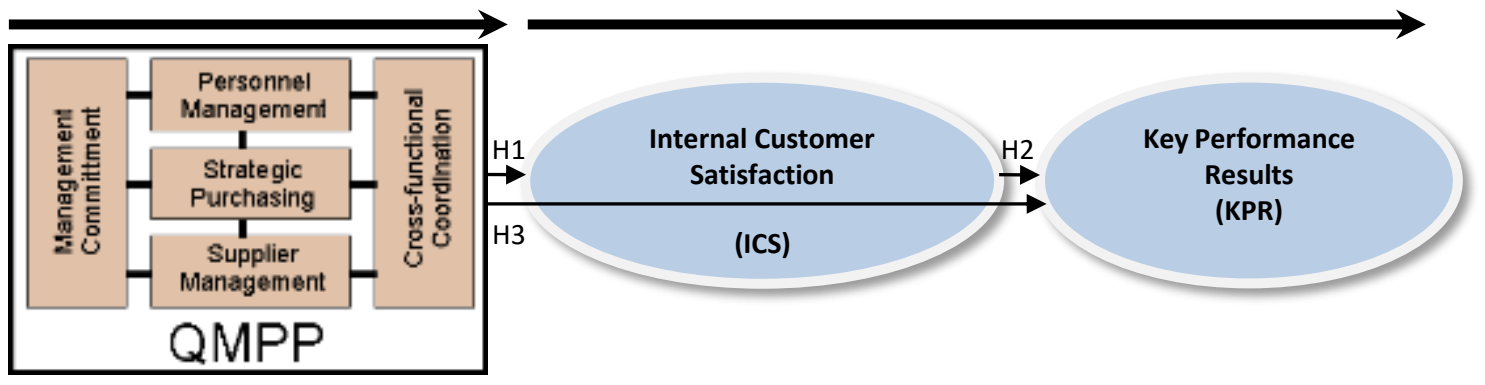

There are three constructs and three relationships portrayed in Figure 2's theoretical model. As we discussed in the literature review, overall there is consistent support in the literature for a positive relationship between quality management, customer satisfaction, and the overall company's operational performance (e.g., Anderson, Rungtusanatham, \& Schroeder, 1994; Choi \& Eboch, 1998; S. Curkovic et al., 2000; Dean \& Bowen, 1994; Kannan $\&$ Tan, 2005). Therefore, it would be reas onable to as sume that the implementation of quality management purchasing would be related with internal customer satisfaction and key business performance results. Measurement and operationalization of each of the constructs is discussed below. 


\subsection{Quality Management Practices in Purchasing and the EFQM Enabler Construct (QMPP)}

As we mentioned earlier, the EFQM enabler construct is composed of five components (see Figure 1) that are linked together in a very complex structure where changes in one dimension relate to changes in other dimensions with all enabler components having a reciprocal interdependence, thereby making individual impacts difficult to discern (BouLlusar et al., 2009). Based on these elements and using the purchasing function as the unit of analysis, a similar set of key elements where mapped onto the EFQM framework to define quality management enablers for purchasing as seen in Figure 2 and Table 1. The following five salient factors define quality management purchasing: supplier quality management, personnel management, cross-functional coordination, management commitment, and strategic purchasing. These five factors together measure the QMPP construct. The methods and structure of the QMPP construct are similar to the Enabler Excellence construct used by Bou-Llusar et al. (2009) in their seminal work "An empirical assessment of the EFQM Excellence model."

A brief description of each EFQM factor, the associated purchasing factors, and selected literature that supports and describes it is presented in Table 1.

Table 1. Operationalization and Mapping of the EFQM Enabler Construct in the Quality Management Purchasing Content

\begin{tabular}{|c|c|c|c|}
\hline EFQM & Operationalized in Purchasing & Description & Selectedliterature \\
\hline Leadership & Management commitment (MC) & $\begin{array}{l}\text { Purchasing management } \\
\text { committed to total quality }\end{array}$ & $\begin{array}{l}\text { Ahire, Golhar, and Waller (1996), } \\
\text { Anderson et al. (1994), Black and Porter } \\
\text { (1996), S Curkovic et al. (2000), Flynn et } \\
\text { al. (1994), Hemsworth et al. (2008), Powell } \\
\text { (1995), Saraph et al. (1989) }\end{array}$ \\
\hline Strategy & Strategic Purchasing (SP) & $\begin{array}{l}\text { Evaluation and improvement of } \\
\text { the company's purchasing } \\
\text { process and performance by } \\
\text { analyzing other organizations' } \\
\text { purchasing process and } \\
\text { performance }\end{array}$ & $\begin{array}{l}\text { Ahire et al. (1996), Black and Porter } \\
\text { (1996), Camp (1989), A. Carr and Smeltzer } \\
\text { (1999), Powell (1995), Hackman and } \\
\text { Wageman (1995) }\end{array}$ \\
\hline People & Personnel management (PM) & $\begin{array}{l}\text { M anagement of employees } \\
\text { based on empowerment, } \\
\text { training, teamwork, performance } \\
\text { evaluation, and reward and } \\
\text { recognition }\end{array}$ & $\begin{array}{l}\text { Ahire et al. (1996), Anderson et al. (1994), } \\
\text { Black and Porter (1996), Carter and } \\
\text { Narasimhan (1994), Carter, Smeltzer, and } \\
\text { Narasimhan (1998), Carter et al. (2000), } \\
\text { S Curkovic et al. (2000), Flynn et al. } \\
\text { (1994), Jiménez-Jiménez and Martínez- } \\
\text { Costa (2009), Perdomo-Ortiz, González- } \\
\text { Benito, and Galende (2009), Powell } \\
\text { (1995), Saraph et al. (1989), Youndt, Snell, } \\
\text { Dean, and Lepak (1996) }\end{array}$ \\
\hline Partnerships & $\begin{array}{l}\text { Supplier quality management } \\
(\mathrm{SQM})\end{array}$ & $\begin{array}{l}\text { Establishment of cooperative } \\
\text { relationships with suppliers and } \\
\text { enhancement of suppliers' } \\
\text { capabilities to improve quality }\end{array}$ & $\begin{array}{l}\text { Carter and Narasimhan (1994), Carter et al. } \\
\text { (1998), A. S. Carr and J. N. Pearson } \\
\text { (1999), Dowlatshahi (1998), Dyer (1997), } \\
\text { Ellram and Hendrick (1995), Foster (2008), } \\
\text { Flynn et al. (1994), Kaynak and Hartley } \\
\text { (2008), D. Krause (1999), D. Krause, } \\
\text { Scannell, and Calantone (2000), Lascelles } \\
\text { and Dale (1989), Powell (1995), Saraph et } \\
\text { al. (1989), Stuart and Mueller (1994), Trent } \\
\text { and Monczka (1999) }\end{array}$ \\
\hline Processes & $\begin{array}{l}\text { Cross-functional coordination } \\
\text { (CFC) }\end{array}$ & $\begin{array}{l}\text { Coordination with other } \\
\text { functional areas in the company } \\
\text { to improve quality }\end{array}$ & $\begin{array}{l}\text { Anderson et al. (1994), Burt (1989), Carter } \\
\text { and Narasimhan (1994), Carter et al. } \\
\text { (1998), A. S. Carr, Kay nak, and } \\
\text { Muthusamy (2008), Dean and Bowen } \\
\text { (1994), Giunipero and Vogt (1997), Yu et } \\
\text { al. (2010) }\end{array}$ \\
\hline
\end{tabular}




\subsection{Purchasing's Internal Customer Satisfaction EFQM Result Construct (ICS)}

The EFQM model measures customer satisfaction as one of its result components. In the purchasing department context, the customers are the department/individuals within the company for whom materials or services are purchased and thus are referred to as the internal customer. Several studies in the literature have used the concept of service quality to evaluate internal customer satisfaction levels (Jun \& Cai, 2010; Stanley \& Wisner, 1998; 2001; 2002; Young \& Varble, 1997). A widely used instrument to measure customer satisfaction has been the SERVQUAL questionnaire developed by Parasuraman, Zeithaml, and Berry (1985) and Parasuraman, Zeithaml, and Berry (1988). Accordingly, customer satisfaction was operationalized following the set of service quality dimensions identified by Parasuraman et al. (1985) and Parasuraman et al. (1988), namely reliability (the ability of the purchasing department to perform the promised service dependably and accurately), responsiveness (the willingness of the purchasing department to help internal customers and provide prompt service), assurance (the knowledge and courtesy of the purchasing department's employees and their ability to convey trust and confidence), empathy (the caring, individualized attention the purchasing department provides to customers), and tangibles (the appearance of the purchasing department's physical facilities, equipment, personnel, and communication material). Although some authors have argued that performance-based measures are more effective for evaluating service quality than SERVQUAL (e.g., Cronin \& Taylor, 1994; Teas, 1994), a recent review of twenty years of SERVQUAL research by Ladhari (2009) revealed that SERVQUAL remains useful for service quality research. The SERVQUAL model was chosen as the measurement tool for this investigation because it is widely used for research and provides the breadth and accuracy to capture the complexities of the internal customer satisfaction construct. Future res earch could attempt to compare and contrast these two models by incorporating performance-based measures into this construct's operationalization.

\subsection{EFQM Key Performance Results Construct (KPR)}

The final result component of the EFQM model involves key performance results. In the purchasing department context, the performance results are reflected in the organization's business performance measures. Research has shown that to effectively capture a firm's performance, organizations should measure performance in multiple dimensions (Kaplan \& Norton, 2001) to include measures of both internal and external performance. This construct is composed of four indicators of a company's overall effectiveness. It corresponds to external and internal measures and was based on work done by Azadegan and Pai (2008). These measures consist of the external measures: return on assets (A. Carr \& Smeltzer, 1999; S. Curkovic et al., 2000; Tan et al., 1999), return on sales (Tan et al., 1999), and market share (e.g., A. Carr \& J. Pearson, 1999; S Curkovic et al., 2000; Tan et al., 1999) and internal measure: production costs (e.g., Narasimhan \& Das, 1999; Tan et al., 1999). Therefore the operationalization of the EFQM performance construct includes multiple key performance indicators - both internal and external measures.

\subsection{Hypotheses}

A fundamental premise in TQM literature is that the introduction of a TQM initiative leads to improved company performance and competitiveness. This premise is adopted by the EFQM Excellence Model which claims that "excellent results with respect to performance, customers, people and society are achieved through leadership driving policy and strategy, which is delivered through people, partnerships and resources, and processes" (EFQM, 2005). In short, quality management purchasing should correlate positively with key performance results; otherwise there will be little company interest in its implementation. Based on this premise and the general EFQM model presented in Figure 1, as well as the model presented in Figure 2 where the purchasing specific enablers and resultants are mapped onto the general EFQM model, the following hypotheses were developed.

H1: Quality management practices in purchasing have a significant direct positive relationship with internal customer satisfaction.

H2: Internal customer satisfaction has a significant direct positive relationship with the key performance measures.

H3: Quality management practices in purchasing have a significant indirect (mediated) positive relationship with business's key performance measures via internal customer satisfaction. 


\section{METHOD}

\subsection{Sample Description}

The EFQM European quality management model is widely utilized in Spain and in countries with similar economies. Spain's economy has been identified as the fifth largest in the EU (E.C., 2012) with manufacturing identified as one of the country's main sectors (B.C.S.S.L., 2011). According to Sánchez and Mora (2002) Spain has similar industrial policies to other EU countries, Spain is a good representation of southern nations of the EU (Spain, Italy and Greece) if not all the EU countries (PewResearch, 2013). As such the importance of Spain in representing the EU is reflected by the number of studies on the EFQM model in this context such as studies of adaptation of EFQM model to health care (Lorenzo et al., 1999), total quality management in urban hotels (Soriano, 1999), EFQM model criteria (CalvoMora, Leal, \& Roldán, 2005), quality management models and company results (Heras Saizarbitoria, 2006), total quality management and performance (Santos-Vijande \& Alvarez-Gonzalez, 2007) and quality management and quality outcome (Tari, Molina, \& Castejon, 2007). A similar study by Bou-Llusar et al. (2009) evaluating the EFQM excellence model relative to the MBNQA model was similarly conducted using manufacturing in Spain (this study did not apply to purchasing). Nevertheless, there is little research on the EFQM model within the purchasing unit in the context of the Spanish manufacturing sector. On the basis of the above, this study focuses on Spanish manufacturers.

The sample frame consisted of 1,200 purchasing managers who were selected (convenience sampling) from the Dun and Bradstreet database (informa.es) of the largest manufacturing companies in Spain. Purchasing managers were determined as the most appropriate respondents because they are most familiar with their organization's purchasing practices and performance outcomes. The survey was administered in three mailings following a modified version of Total Design (Dillman, 1978) for survey research. In the first mailing, a cover letter explaining the purpose of the study and a survey questionnaire along with a postage-paid envelope were sent to all members in the sample frame. A letter encouraging non-respondents to participate in the research was sent three weeks later. Six weeks after the initial mailing, a second survey and cover letter were sent to the remaining non-respondents. The respondent sample was composed of high-level purchasing executives, including 145 directors of purchasing (48\%), 89 general managers of purchasing (29\%), 19 purchasing managers (6\%), and 45 "other" titles (17\%).

Of the 1,200 surveys mailed, eight were returned undeliverable. Three hundred and six usable responses were received, which translates into a 25 percent response rate. Two approaches were used to assess non-response bias. The first approach consisted of comparing early with late respondents following Armstrong and Overton (1977) recommendations. No significant differences were found between early and late respondents on such variables as sales volume, number of employees, or cost of raw materials and components. The second approach involved comparing sales and number of employees between responding firms and non-responding firms (see Table 2). Because no significant differences were found between the two sample groups, the respondent group's sample considered similar to the targeted industries.

Respondents reported an average of 779 employees. Fifty percent of the companies employed between 101 and 500 employees (155 firms). The largest firm employed 15,000 workers and had the highest annual sales (€5.4 billion). A diverse group of manufacturing organizations participated in the study. In descending order of response frequency, food, automotive components, miscellaneous manufacturing, and chemicals were the most widely represented industries in the respondent group (see Table 3). Annual gross sales of the companies surveyed ranged from 34 million Euros $(€)$ to $€ 5.4$ billion, with an average annual sales of $€ 141$ million. 
Table 2. Comparisons Between Respondents and Non-respondents (Dun \& Bradstreet Database)

\begin{tabular}{l|l|c|c|c|c}
\hline & & n & Mean & Standard deviation & Significance \\
\hline \multirow{2}{*}{ Sales (million Euros $€$ ) } & Non-respondents & 898 & 169.38 & 514.11 & 0.383 \\
\cline { 2 - 6 } & Respondents & 302 & 141.61 & 349.83 & \\
\hline \multirow{2}{*}{ Number of employees } & Non-respondents & 890 & 536 & 1,024 & 0.637 \\
\cline { 2 - 6 } & Respondents & 302 & 568 & 932 & \\
\hline
\end{tabular}

Table 3. Respondents' Industries as Reported in the Sample

\begin{tabular}{l|c|c}
\hline \multicolumn{1}{c}{ Industry } & Frequency & Percentage \\
\hline Food and beverage & 58 & $18.9 \%$ \\
\hline Auto components & 46 & $15.0 \%$ \\
\hline Miscellaneous manufacturing & 40 & $13.4 \%$ \\
\hline Chemicals & 38 & $12.4 \%$ \\
\hline Machinery & 20 & $6.5 \%$ \\
\hline Pharmaceutical products & 15 & $4.9 \%$ \\
\hline Construction materials & 14 & $4.6 \%$ \\
\hline Telecommunications \& electronic equipment & 12 & $3.9 \%$ \\
\hline Electricity materials & 12 & $3.9 \%$ \\
\hline Primary metals & 12 & $3.9 \%$ \\
\hline Paper & 11 & $3.6 \%$ \\
\hline Electric appliances & 10 & $3.3 \%$ \\
\hline Non-ferrous metallurgy & 9 & $2.9 \%$ \\
\hline Textile & 9 & $2.9 \%$ \\
\hline Total & 306 & $100.0 \%$ \\
\hline
\end{tabular}

\subsection{Scale Development}

A list of quality management purchasing activities was compiled based on the literature reviewed as depicted in Table 1. Operations management faculty were used as expert judges for content validation to determine how well the chosen items represented the defined constructs. Purchasing managers at five manufacturing sites were interviewed while they reviewed the variables and items included in the survey questionnaire to identify any language ambiguities and perceived omissions of other relevant practices not included in the survey. There were no significant variables missing in the pilot study questionnaire but only minor wording discrepancies and comments which were then used to further refine the survey instrument.

The survey instrument measured 23 items related to quality management purchasing (see Table 4), four items related to business performance, and five items related to internal customer satisfaction (see Table 5). In order to measure those items, respondents were asked to indicate their degree of agreement or disagreement with the listed statements using five-point labeled Likert scales, where one represented "strongly disagree" and five represented "strongly agree." For example, for item V1 in Table 4, pertaining to predominance of quality over other purchasing objectives, the question in the survey instrument was, "Indicate your agreement or disagreement with the following statement: Purchasing management communicates to purchasing employees that quality is the most important purchasing objective." 
Table 4. Scale Development Quality Management Purchasing CFA Loadings

\begin{tabular}{|c|c|c|c|c|}
\hline & Construct / Item & $\begin{array}{l}\text { Standardized } \\
\text { coefficient } * *\end{array}$ & $t$-value & p-value \\
\hline & Management commitment (MC) $\alpha=0.71$ & & & \\
\hline V1 & Predominance of quality over other purchasing objectives & 0.793 & 13.112 & 0.000 \\
\hline V2 & Purchasing management's evaluation based on quality & 0.633 & 10.465 & 0.000 \\
\hline \multirow[t]{2}{*}{$\mathrm{V} 3$} & Predominance of quality in supplier selection and evaluation & 0.569 & 9.336 & 0.000 \\
\hline & Cross-functional coordination (CFC) $\alpha=0.69$ & & & \\
\hline V4 & Purchasing's interaction with quality & 0.600 & 9.603 & 0.000 \\
\hline V5 & Purchasing's interaction with production & 0.741 & 11.814 & 0.000 \\
\hline \multirow[t]{2}{*}{ V6 } & Purchasing's interaction with new product development & 0.600 & 9.594 & 0.000 \\
\hline & personnel management $(\mathrm{PM}) \alpha=0.75$ & & & \\
\hline V7 & Job autonomy & 0.478 & 8.040 & 0.000 \\
\hline V8 & Job security & 0.636 & 11.282 & 0.000 \\
\hline V9 & Involvement in decisions & 0.517 & 8.805 & 0.000 \\
\hline V10 & Training & 0.666 & 11.944 & 0.000 \\
\hline V11 & Teamwork & 0.695 & 12.605 & 0.000 \\
\hline \multirow[t]{2}{*}{ V12 } & Reward and recognition & 0.483 & 8.138 & 0.000 \\
\hline & Supplier quality management (SQM) $\alpha=0.76$ & & & \\
\hline V13 & Certification of suppliers under ISO 9000 & 0.430 & 7.195 & 0.000 \\
\hline V14 & Supplier evaluation & 0.713 & 13.169 & 0.000 \\
\hline V15 & Supplier reward and recognition & 0.558 & 9.695 & 0.000 \\
\hline V16 & Training for suppliers & 0.609 & 10.783 & 0.000 \\
\hline V17 & Supply base rationalization & 0.206 & 3.317 & 0.000 \\
\hline V18 & Sharing of information & 0.677 & 12.320 & 0.000 \\
\hline \multirow[t]{2}{*}{ V19 } & Interaction with suppliers in materials improvement & 0.688 & 12.572 & 0.000 \\
\hline & Strategic Purchasing (SP) $\alpha=0.80$ & & & \\
\hline V20 & Purchasing involvement in strategic planning process & 0.512 & 8.74 & 0.000 \\
\hline V21 & Purchasing long-term planning & 0.868 & 10.53 & 0.000 \\
\hline V22 & Level of purchasing manager in organization & 0.695 & 11.00 & 0.000 \\
\hline V23 & Alignment of purchasing and company strategy & 0.735 & 11.56 & 0.000 \\
\hline
\end{tabular}

Table 5. Scale Development Measurement Model CFA Results

\begin{tabular}{|c|c|c|c|c|}
\hline & Construct / Item & $\begin{array}{l}\text { Standardized } \\
\text { Coefficient*** }\end{array}$ & $t$-value & $p$-value \\
\hline & Quality management practices in purchasing (QMPP) $\alpha=0.73$ & & & \\
\hline CV1 & Management commitment (MC) & 0.49 & 8.07 & 0.000 \\
\hline CV2 & Cross-functional coordination (CFC) & 0.49 & 8.05 & 0.000 \\
\hline $\mathrm{CV} 3$ & Personnel management (PM) & 0.80 & 14.01 & 0.000 \\
\hline CV4 & Supplier quality management (SQM) & 0.63 & 10.77 & 0.000 \\
\hline \multirow[t]{2}{*}{ CV5 } & Strategic Purchasing (SP) & 0.62 & 10.63 & 0.000 \\
\hline & Business performance (BP) $\alpha=.76$ & & & \\
\hline V24 & Return on Assets (Profit / total assets) & 0.47 & 8.05 & 0.000 \\
\hline V25 & Sales margin (Profit / Sales) & 0.65 & 12.85 & 0.000 \\
\hline V26 & Production costs & 0.80 & 17.33 & 0.000 \\
\hline \multirow[t]{2}{*}{ V27 } & Market share & 0.82 & 19.12 & 0.000 \\
\hline & Internal customer satisfaction (ICS) $\alpha=0.69$ & & & \\
\hline V28 & Reliability & 0.45 & 7.25 & 0.000 \\
\hline V29 & Empathy & 0.71 & 12.48 & 0.000 \\
\hline $\mathrm{V} 30$ & Assurance & 0.43 & 7.038 & 0.000 \\
\hline V31 & Responsiveness & 0.76 & 13.43 & 0.000 \\
\hline$*$ & Tangibles & - & - & - \\
\hline
\end{tabular}

*Item dropped during validity and reliability analy ses; **St andardized loadings are calculated from the confirmatory factor analyses performed on each scale/subscale (not the model tested in Figure 3). 


\section{RESEARCH RESULTS}

\subsection{Analyses}

Data were initially entered into Microsoft Excel 2003 and then Excel 2010 for preprocessing, data cleansing, and determination of scale composites. Pairwise deletion, rather than mean substitution, was employed for missing data. IBM SPSS Version 19 (IBM, 2010)was then used for the statistical analyses and Lis rel 8.8 (K. G. Jöreskog \& Sörbom, 2006) for the confirmatory factor analyses and structural equation modeling (SEM). Confirmatory factor analyses (CFA) were conducted on all scales and subscales. All tests were two-tailed, and the level of significance was set at .05 , so $p$-values $\alpha=.05$ were reported as statistically significant unless otherwise specified. The model and hypotheses were tested using SEM. SEM is an appropriate statistical technique when assessing the relationships among latent constructs that are measured by multiple scale items, where at least one construct is both a dependent and an independent variable (Hair, Anderson, Tatham, \& Black, 1995).

\subsection{Construct Validation}

Confirmatory factor analysis (CFA) was conducted to address the reliability and validity of the study's constructs (Anderson \& Gerbing, 1988). We first examined the convergent validity of all constructs utilized in this study through a confirmatory factor analysis. Multiple-fit criteria were used to as sess the appropriateness of the measurement models tested (Bollen \& Long, 1993; Hair et al., 1995).

Convergent validity is demonstrated when a set of altern ative measures accurately represents the construct of interest (Churchill, 1979). For this study, convergent validity was assessed by reviewing the level of significance for the factor loadings. If all the individual item's factor loadings are significant, then the indicators are effectively measuring the same construct (Anders on \& Gerbing, 1988). For each of the three constructs the CFAs indicated a good fit; QMPP $-\chi^{2}=7.72, p=0.05, d f=9, \chi^{2} / d f=0.85, \mathrm{RMSEA}=0.05, \mathrm{RMSR}=0.04, \mathrm{CFI}=1.00, \mathrm{GFI}=0.99, \mathrm{AGFI}=0.96 ; \underline{\mathrm{ICS}}$ $-\chi^{2}=2.01, d f=2, p=0.05, \chi^{2} / d f=1.0, \mathrm{RMSEA}=0.05, \mathrm{RMSR}=0.04, \mathrm{CFI}=1.00, \mathrm{GFI}=0.99$, AGFI $=0.96$; $\underline{\mathrm{BP}}-$ $-\chi^{2}=0.01, d f=1, p=0.93, \chi^{2} / d f=0.01, \mathrm{RMSEA}=0.00, \mathrm{RMSR}=0.00, \mathrm{CFI}=1.00, \mathrm{GFI}=1.00, \mathrm{AGFI}=1.00$.

The fit indices for the CFA showed values above or equal to the recommended minimum levels $\left(p>=0.05, \chi^{2} / d f<\right.$ 3.0, RMSEA < 0.10, RMSR <0.10, CFI > 0.90, GFI > 0.90, AGFI >0.90). As can be seen in Table 4 and Table 5, the coefficients for all indicators were high and strongly significant ( $t$-values $>2.576 ; p<0.01$ ). These results provide satisfactory evidence of convergent validity for the indicators used to measure the constructs in this study.

Discriminant validity among the latent variables and their as sociated measurement variables can be assessedby fixing (i.e., constraining) the correlation between pairs of constructs to 1.0, then re-estimating the modified model (Segars \& Grover, 1993). This procedure essentially converts a two-construct model into a single-construct model. The condition of discriminant validity is met if the difference of the chi-square statistics between the constrained and standard models is significant $(1 \mathrm{df})$. The chi-square difference tests indicated that discriminant validity exists among all of the constructs that make up the quality management practices in purchasing (SQM, PM, CFC, MC, and SP) ( $p$ $<0.01$ ). Discriminant validity also exists between the constructs of QMPP, information systems, and business performance.

Scale reliability provides a measure of the internal homogeneity of the items comprising a scale (Churchill, 1979) and was calculated as follows: (square of summation of factor loadings) / [(square of summation of factor loadings) + (summation of error variances)] (Fornell \& Larcker, 1981; Hair et al., 1995). With the exception of only crossfunctional coordination, all quality management purchasing constructs dis played composite reliability values in excess of 0.70 (see Table 4), and all were above the recommended minimum of 0.60 for exploratory studies (Churchill, 1979), providing enough evidence of the reliability of the scales used. We aggregated the scores for all five qualitymanagement constructs by calculating the average of the individual scores for the items making up each construct, and thus obtained the composite variables CV1 to CV5 (see Figure 2). For example, the mean of the responses from manifest variables V1 to V3 was computed to determine the composite measure for management commitment (CV1). 


\subsection{Hypothesis Testing}

The hypothes es were tested using structural equation modeling (SEM) as depicted in Figure 3. SEM is an appropriate statistical technique when assessing the relationships among latent constructs that are measured by multiple scale items, where at least one construct is both a dependent and an independent variable (Hair et al., 1995). For this reas on, we tested the study's hypotheses using structural equation modeling.

Figure 3. Results from the Structural Model Analy sis

\section{EFQM Enablers $\quad$ EFQM Results}

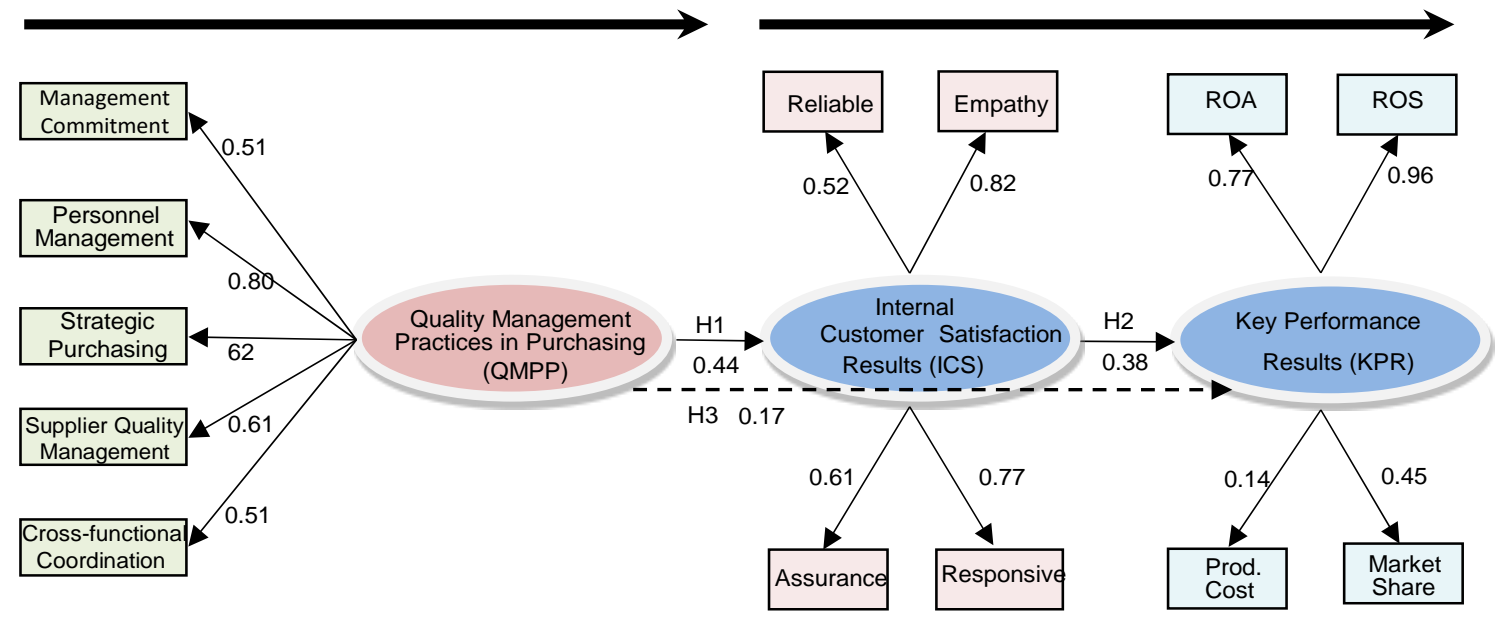

${ }^{*}$ Chi-square $=115.55 \quad P$-value $=0.00004$ RMSEA $=0.053$

All values in the model were significant $p<.01$

Prior to ass essing the study's hypotheses, the model's overall fit must be established (Bollen \& Long, 1993). The chisquare statistic was significant $\left(\chi^{2}=115.55 ; d f=62 ; p=0.00004\right)$. However, the chi-square estimate has been shown to be oversensitive to small model discrepancies when sample sizes are larger than 200, or when the model contains a large number of variables (i.e., the model is complex) (Bagozzi \& Yi, 1988; Byrne, 1994; Hair et al., 1995). With respect to this oversensitivity, Hair et al. (1995) suggest using the whole data set to estimate the correlation structure and to set the number of observations used to estimate the significance of $\chi^{2}$ to 200 (this is achieved in LISREL by setting the " $\mathrm{N}=$ " portion of the "Data" line to 200). Utilizing this procedure yielded a non-significant $\chi^{2}=75.39, p=$ 0.12 , which indicates a good model fit. The fit indices indicated a good fit between the data and the model. The ratio $\chi^{2} / d f(106.58 / 62)$ and RMS, with values of 1.87 and 0.068 , respectively, were below the recommended maximu $\mathrm{m}$ of 3.00 and 0.10 (Chau, 1997). Similarly, the index RMSEA was below the 0.10 minimum acceptable level, with a value of 0.053 . Additionally, the indices NNFI, CFI, IFI, and GFI were all above the minimum acceptable 0.90 level, with values of $0.95,0.96,0.96$, and 0.94 , respectively. The $\mathrm{CN}$ exceeded the critical value of 200 at 236.89 . The resu lts of the structural model estimation are shown in Figure 4. The model appears to fit reasonably well(Martínez-López, Gázquez-Abad, \& Sousa, 2013).

The test of the proposed hypotheses is based on the direct and indirect effects of the structural model presented in Figure 3. LISREL coefficients between latent variables give an indication of the relative strength of each relationship (K. Jöreskog \& Sörbom, 1993). Each of the three hypotheses was tested at the significance level $p<0.05$. All 13 measurement variables loaded significantly $(p<0.05)$ on their respective constructs (QMPP, ICS, and BP).

The first hypothes is as serts that quality management practices in purchasing have a positive direct relationship with internal customer satisfaction. According to the results shown in Figure 2, the path relating these two constructs was positive and significant ( tandardized $\gamma_{1}$ coefficient $=0.44 ; t$-value $=4.73 ; p<0.05$ ). This provides strong evidence supporting hypothesis 1 and indicates that the adoption of quality management practices in purchasing increases the 
level of internal customer satisfaction. This supports Jun and Cai (2010)'s research the positive relationship between internal service quality and internal customer satisfaction.

The second hypothesis posits that internal customer satisfaction has a positive direct relationship with business performance. According to the results shown in Figure 2, the path between quality management purchasing and internal customer satisfaction was positive and significant (standardized $\gamma 2$ coefficient $=0.38 ; t$-value $=2.18 ; p<$ 0.05). This provides strong evidence supporting hypothesis 2 and indicates that increases in internal customer satisfaction directly increase the level of business performance. This supports research that suggests internalcustomer orientation leads to improved performance, supply chain management, and external and internal marketing (Panigyrakis \& Theodoridis, 2009; Yu et al., 2010).

The third hypothesis asserts that quality management practices in purchasing have a positive indirect (mediated) relationship with business performance via internal customer satisfaction. According to the results shown in Figure 3, the path relating these two constructs was positive and significant ( tandardized $\beta 1$ coefficient $=0.17 ; \mathrm{t}$-value $=2.37$; $\mathrm{p}<0.05$ ). This provides strong evidence supporting hypothesis 3 . This result indicates that when we adopt quality management practices in purchasing, the level of business performance is also expected to improve not directly but indirectly, as mediated by internal customer satisfaction. This confirms Sánchez-Rodríguez et al. (2004)'s study that indicates quality management practices in purchasing are associated with purchasing's operational performance and internal customer satisfaction

Therefore, this research provides strong support for the theoretical model (Figure 2) explored here and the viability of the EFQM model used as a framework to describe the relationship between quality management practices in purchasing with both the purchasing's internal customers and the company's business performance.

\section{DISCUSSION AND CONCLUSION}

This is the first study to test the multidimensional structure of the EFQM model as applied to the purchasing function using structural equation modeling to examine the relationships among quality management in purchasing, internal customer satisfaction, and performance. Thus this study represents a unique contribution to the literat ure by 1) establishing and assessing the viability of the EFQM framework to an individual (micro) functional area (i.e., purchasing) as opposed to the traditional macro/organizational level, and 2) examining relationships as hypothesized by the EFQM model among EFQM - enablers (quality management practices in purchasing) and EFQM - results (internal customer satisfaction and key performance results).

With respect to establishing and assessing the viability of the EFQM model for the purchasing function, we first operationalized and applied the five EFQM enablers and two EFQM resultant factors to the purchasing domain. The enablers within the purchasing domain were operationalized as five quality management practices in purchasing - that is, personnel management, cross-functional coordination, and strategic purchasing; as well as two resultant factors, internal customer satisfaction and key performance measures. Confirmatory factor analyses (CFA) were conducted on all the scales and subscales utilized in the model. The results provide strong evidence of the reliability and convergent validity for all the constructs and the as sociated indicators used in the study. Further, the analys is indicates that discriminant validity exists among all of the constructs in the model - that is, quality management practices in purchasing (including all its subscales), internal customer satisfaction, and key performance results. Finally, the purchasing operationalized EFQM model's overall fit was established indicating that the hypothesized EFQM model fit the purchasing data reasonably well. These results therefore establish the viability of the EFQM framework for an individual (micro) functional area (i.e., purchasing).

Next, the three hypotheses implied by the EFQM model were tested. More specifically the relationship between the EFQM enablers (quality management practices in purchasing) and EFQM results (internal customer satisfaction and key performance results) were estimated using structural equation modeling. First, it was found that the EFQM enablers (the five quality management practices in purchasing) had a significant direct positive relationship with improving the EFQM customer satisfaction resultant (purchasing's internal customer satisfaction). This finding is consistent with other findings in the literature such as that of Jun and Cai (2010) who found that internal service quality leads to internal customer satis faction. Second, the study found that an EFQM enabler (purchasing's internal customer 
satisfaction) had a significant direct positive relationship with key performance results (increasing return on assets, return on sales, production costs, and market share). These findings are consistent with other findings in the literature (Harsasi \& Radhi, 2010; Stanley \& Wisner, 1998, 2001, 2002) (EFQM, 2005; Harsasi \& Radhi, 2010; Stanley \& Wisner, 1998, 2001, 2002). Finally, the study identifies quality management practices' positive relationship with purchasing on key performance results as mediated by internal customer satisfaction. This finding demonstrates that the implementation of quality management practices in purchasing leads to an improvement in the company's internal customer satisfaction, which in turn improves the key success performance indicators of the organization. Thus the theoretical implications of the EFQM model proposed in Figure 2 was established for the purch asing function which fills a gap between theory and practice that had been previously overlooked in the literature (Brandon-Jones \& Silvestro, 2010; Jun \& Cai, 2010).

The study's findings have both practical and theoretical implications. Managers in the purchasing area seeking to improve their performance by adopting quality management practices such as the EFQM model now have empirical research to demonstrate a positive relationship with key business success indicators, which will aid in making their case to upper management for the associated resources. Additionally, this research is of great importance to upper management who are attempting to improve their company's performance in that they can implement the EFQM model in purchasing and potentially other functional areas within the firm to gain positive results. These findings give them a concrete set of quality management practices that they can implement which will have positive impacts on their company's bottom line.

With respect to theoretical implications, the study raises several important questions and opportunities for future research. First, can the EFQM model be operationalized and applied to other functions beyond the purchasing domain? Second, and perhaps more specific to the purchasing function, would the implementation of the EFQM model help the purchasing function to achieve a more recognized role in the company and increase its strategic import ance? Although this paper does not specifically address whether or not the role of the purchasing department would change with the application of the EFQM model, it provides some indications of what those changes would be in the event of change. For example, by reas on of the purchasing management being involved in the company's overall planning process (strategic purchasing), managing strategic supplier relationships collaboratively (supplier relationships), focusing on team work (purchasing personnel), close coordination of activities with other business functions (crossfunctional coordination), and benchmarking, the purchasing function procurement would strengthen the purchasing function's strategic role.. Additionally, recent research predicts (Rozemeijer, Quintens, Wetzels, \& Gelderman, 2012) that partnerships, collaborations, and social networks (supported by the EFQM model) will continue to increase in importance both externally with suppliers and internally with internal stakeholders, engaging them to support the business strategy and increase customer value and organizational performance. The EFQM model applied to purchasing identifies the key enabling elements that are necessary to develop these partnerships/networks while at the same time focusing on the outcomes of these enablers, including customer results (internal and external) and financial performance results (Rozemeijer et al., 2012). As such, this study points towards a purchasing department as a strategic business process and centered with a special emphasis in sustained supply chain relationships (Tassabehji \& Moorhouse, 2008).

While this study makes important contributions, it has several limitations and opens up many additional opportunities for future research. This study was cross-sectionaland descriptive of a given sample at a given point of time. A more stringent test of the relationships between quality management purchasing, internal customer satisfaction, and performance requires a longitudinal study or field experiment that could gather information about quality management purchasing, internal customer satisfaction, and performance in an appropriate time span. Then the association between the variation of independent factors and the variation of performance could be further investigated. Also, the use of a single key informant could be seen as a potential limitation of the study, and this study's findings should be confirmed in the future using information directly obtained from respondents from the constituent groups of actual suppliers and internal customers. Future research could also better define the path between internal customer satisfaction and performance. It might be that the implementation of the practices included in the constructs of management commitment, cross-functional coordination, personnel management, supplier quality management, quality information, and strategic purchasing contributes to improvements in the quality of materials purchased, ensuring ontime delivery from suppliers, meeting material-expending targets, and achieving inventory goals which add to internal customer satisfaction. Such practices might also provide additional value to external customers which would have an 
impact on business performance. Subsequent research could es tablish the contribution that each makes to performance. Despite these areas for future investigation, the study represents a unique contribution by systematically applying and validating the EFQM model to a specific unit (i.e., purchasing).

\section{ACKNOWLEDGMENT}

The authors wish to thank Cajamurcia (Spain) for its financial support of this research. This research was funded in part by the Social Sciences and Humanities Research Council of Canada.

\section{AUTHOR BIOGRAPHY}

Dr. Hems worth is a Professor of business at Nipissing University, Ontario Canada and has been teaching and researching for over 20 years. He is a statistician that focus on the modelling of multivariate data. His research interests include quality management, leadership, quality of work-life and innovation. Email: davidhe@nipissingu.ca

\section{REFERENCES}

Ahire, S., Golhar, D., \& Waller, M. (1996). Development and validation of TQM implementation constructs. Decision Sciences, 27(1), 23-56.

Amit, R., \& Schoemaker, P. J. (1993). Strategic assets and organizational rent. Strategic Management Journal, 14(1), 33-46.

Anderson, J., \& Gerbing, D. (1988). Structural equation modelling in practice: a review and recommended two-step approach. Psychological Bulletin, 103(2), 411-423.

Anderson, J., Rungtusanatham, M., \& Schroeder, R. (1994). A theory of quality management underlying the Deming management method. Academy of Management Review, 19(3), 472-509.

Anderson, J., Rungtusanatham, M., Schroeder, R., \& Devaraj, S. (1995). A path analytic model of a theory of quality management underlying the Deming management method: preliminary empirical findings. Decision Sciences, 26(5), 137-148.

Armstrong, J., \& Overton, T. (1977). Estimating non-response bias in mail survey s. Journal of Marketing Research, 14(3), 396402.

Azadegan, A., \& Pai, D. (2008). Industrial awards as manifests of business performance: An empirical assessment. Journal of purchasing and supply management, 14(3), 149-159.

B.C.S.S.L. (2011). Spain: Major Business Sectors. Madrid, Spain: OSEC Business Network Switzerland.

Bagozzi, R., \& Yi, Y. (1988). On the evaluation of structural equation models. Academy of Marketing Science, 6(1), 74-93.

Barney, J. (1991). Firm resources and sustained competitive advantage. Journal of Management, 17(1), 99-120.

Barney, J. B. (1986). Strategic factor markets: Expectations, luck, and business strategy. Management Science, 32(10), 12311241.

Björklund, M. (2010). Benchmarking tool for improved corporate social responsibility in purchasing. Benchmarking: An International Journal, 17(3), 340-362.

Black, S., \& Porter, L. (1996). Identification of the critical factors of TQM. Decision Sciences, 27(1), 1-21.

Bollen, K., \& Long, J. (1993). Testing Structural Equation Models. Newbury Park, CA: Sage Publications.

Bou-Llusar, J. C., Escrig-Tena, A. B., Roca-Puig, V., \& Beltrán-Martín, I. (2005). To what extent do enablers explain results in the EFQM excellence model?: An empirical study. International Journal of Quality \& Reliability Management, 22(4), 337-353.

Bou-Llusar, J. C., Escrig-Tena, A. B., Roca-Puig, V., \& Beltrán-Martín, I. (2009). An empirical assessment of the EFQM Excellence Model: Evaluation as a TQM framework relative to the MBNQA Model. Journal of Operations Management, 27(1), 1-22.

Brandon-Jones, A., \& Silvestro, R. (2010). Measuring internal service quality: comparing the gap-based and perceptions-only approaches. International Journal of Operations \& Production Management, 30(12), 1291-1318.

Brookshaw, T., \& Terziovski, M. (1997). The relationship between strategic purchasing and customer satisfaction within a total quality management environment. Benchmarking for Quality Management \& Technology, 4(4), 244-258.

Burt, D. (1989). Managing product quality through strategic purchasing. Sloan Management Review, 30(3), 39-48.

Byrne, B. (1994). Structural Equation Modelling with EQS and EQS/Windows: Basic Concepts, Applications, and Programming. Thousand Oaks, CA: Sage Publications.

Caddick, R., \& Dale, B. (1998). The impact of total quality management on the purchasing function: influences and implications. European Journal of Purchasing and Supply Management, 4, 133-142.

Calvo-Mora, A., Leal, A., \& Roldán, J. L. (2005). Relationships between the EFQM model criteria: a study in Spanish universities. Total Quality Management \& Business Excellence, 16(6), 741-770. 
Camp, R. (1989). Benchmarking: The Search for Industry Best Practices that Lead to Superior Performance. Milwaukee, WI: ASQC Press.

Carr, A., \& Pearson, J. (1999). Strategically managed buyer-supplier relationships and performance outcomes. Journal of Operations Management, 17(5), 497-519.

Carr, A., \& Smeltzer, L. (1999). The relationship among purchasing benchmarking, strategic purchasing, firm performance, and firm size. The Journal of Supply Chain Management, 35(5), 51-60.

Carr, A. S., Kaynak, H., \& Muthusamy, S. (2008). The cross-functional coordination between operations, marketing, purchasing and engineering and the impact on performance. International Journal of Manufacturing Technology and Management, 13(1), 55-77.

Carr, A. S., \& Pearson, J. N. (1999). Strategically managed buyer-supplier relationships and performance outcomes. Journal of Operations Management, 17(5), 497-519.

Carter, J., \& Narasimhan, R. (1994). The role of purchasing and materials management in total quality management and customer satisfaction. International Journal of Purchasing and Materials Management, 30(3), 2-13.

Carter, J., Smeltzer, L., \& Narasimhan, R. (1998). The role of buyer and supplier relationships in integrating TQM through the supply chain. European Journal of Purchasing and Supply Management, 4(4), 223-234.

Carter, J., Smeltzer, L., \& Narasimhan, R. (2000). Human resource management within purchasing management: its relationship to Total Quality Management success. The Journal of Supply Chain Management, 36(2), 52-62.

Chau, P. (1997). Re-examining a model for evaluating information center success using a structural equation modelling approach. Decision Sciences, 28(2), 309-334.

Choi, T., \& Eboch, K. (1998). The TQM paradox: relations among TQM practices, plant performance, and customer satisfaction. Journal of Operations Management, 17(1), 59-75.

Churchill, G. (1979). A paradigm for developing better measures of marketing constructs. Journal of Marketing Research, 16(1), 64-73.

Cooper, M., Lambert, D., \& Pagh, J. (1997). Supply chain management: more than a new name for logistics. International Journal of Logistics Management, 8(1), 1-13.

Cronin, J., \& Taylor, S. (1994). SERVPERF versus SERVQUAL: reconciling performance-based and perceptions-minusexpectations measurement of service quality. Journal of Marketing, 58(1), 125-131.

Curkovic, S., Shawnee, V., \& Droge, C. (2000). Quality-related Action Programs: Their Impact on Quality Performance and Firm Performance. Decision Sciences, 31(4), 885-905.

Curkovic, S., Vickery, S., \& Droge, C. (2000). Quality-related elements: their impact on quality performance and firm performance. Decision Sciences, 31(4), 885-905.

Dean, J., \& Bowen, D. (1994). Management theory and total quality: improving research and practice through theory development. Academy of Management Review, 19(3), 392-418.

Dillman, D. (1978). Mail and Telephone Surveys: The Total Design Method. New York: John Wiley.

Dowlatshahi, S. (1998). Implementing early supplier involvement: a conceptual framework. International Journal of Operations \& Production Management, 18(2), 143-167.

Dyer, J. (1997). Effective interfirm collaboration: how firms minimize transaction costs and maximize transaction value. Strategic Management Journal, 18(7), 535-556.

E.C. (2012). Spain: An overview of Spain's economy.: Euro Challenge.

EFQM. (2005). The EFQM framework for risk managment.

Ellram, L., \& Hendrick, T. (1995). Partnering characteristics: a dy adic perspective. Journal of Business Logistics, 16(1), 41-64.

Fawcett, S., \& Fawcett, S. (1995). The firm as a value-added system: integrating logistics, operations and purchasing. International Journal of Physical Distribution \& Logistics Management., 25(5), 24-42.

Flynn, B., Sakakibara, S., \& Schroeder, R. (1994). A framework for quality management research and an associated measurement instrument. Journal of Operations Management, 11(4), 339-366.

Fornell, C., \& Larcker, D. (1981). Evaluating structural equation models with unobservable variables and measurement error. Journal of Marketing Research, 18, 39-50.

Foster, S. T. (2008). Towards an understanding of supply chain quality management. Journal of Operations Management, 26(4), 461-467.

Fredendall, L. D., Hopkins, C. D., \& Bhonsle, A. (2005). Purchasing's internal service performance: critical external and int ernal determinants. Journal of Supply Chain Management, 41(2), 26-38.

Giunipero, L., \& Brand, R. (1996). Purchasing's role in supply chain management. International Journal of Logistics Management, 7(1), 29-38.

Giunipero, L., \& Vogt, J. (1997). Empowering the purchasing function: moving to team decisions. International Journal of Purchasing and Materials Management, 33(1), 8-15.

Hackman, R., \& Wageman, R. (1995). Total quality management: empirical, conceptual, and practical issues. Administrative Science Quarterly, 40(2), 309-342.

Hair, J. F., Anderson, R., Tatham, R., \& Black, W. (1995). Multivariate Data Analysis with Readings (4 ed.). Englewood Cliffs, NJ: Prentice Hall. 
Harsasi, M., \& Radhi, F. (2010). The Influence of Implementing Quality Management Towards Purchasing Performance and Competitive Advantage Making. Journal of Indonesian Economy and Business, 25(1).

Hemsworth, D., Sánchez-Rodríguez, C., \& Bidgood, B. (2008). A structural model of the impact of Quality Management Practices and purchasing-related Information Systems on purchasing performance: A TQM perspective. Total Quality Management, 19(1-2), 151-164.

Heras Saizarbitoria, I. (2006). How quality management models influence company results-conclusions of an empirical study based on the Delphi method. Total Quality Management \& Business Excellence, 17(6), 775-794.

Hides, M. T., Davies, J., \& Jackson, S. (2004). Implementation of EFQM excellence model self-assessment in the UK higher education sector-lessons learned from other sectors. The TQM Magazine, 16(3), 194-201.

Hsu, C. C., Tan, K., Kannan, V. R., \& Leong, G. K. (2009). Supply chain management practices as a mediator of the relationship between operations capability and firm performance. International Journal of Production Research, 47(3), 835-855.

Hult, G. T. M., Ferrell, O., Hurley, R. F., \& Giunipero, L. C. (2000). Leadership and relationship commitment: a focus on the supplier-buy er-user linkage. Industrial Marketing Management, 29(2), 111-119.

IBM. (2010). IBM SPSS Statistics for Windows. Armonk, NY: IBM Corp.

Jacobs, B., \& Suckling, S. (2007). Assessing customer focus using the EFQM Excellence Model: a local government case. The TQM Magazine, 19(4), 368-378.

Jiménez-Jiménez, D., \& Martínez-Costa, M. (2009). The performance effect of HRM and TQM: a study in Spanish organizations. International Journal of Operations \& Production Management, 29(12), 1266-1289.

Jöreskog, K., \& Sörbom, D. (1993). LISREL 8: Structural Equation Modelling with the SIMPLIS Command Language. ChicagoIL: Scientific Software International.

Jöreskog, K. G., \& Sörbom, D. (2006). LISREL 8.8 for Windows Skokie, IL: Scientific Software International, Inc.

Jun, M., \& Cai, S. (2010). Examining the relationships between internal service quality and its dimensions, and internal cust omer satisfaction. Total Quality Management, 21(2), 205-223.

Kannan, V. R., \& Tan, K. C. (2005). Just in time, total quality management, and supply chain management: understanding their linkages and impact on business performance. Omega, 33(2), 153-162.

Kaplan, R. S., \& Norton, D. P. (2001). Transforming the balanced scorecard from performance measurement to strategic management: Part I. Accounting horizons, 15(1), 87-104.

Kaynak, H. (2003). The relationship between total quality management practices and their effects on firm performance. Journal of Operations Management, 21(4), 405-435.

Kaynak, H., \& Hartley, J. L. (2008). A replication and extension of quality management into the supply chain. Journal of Operations Management, 26(4), 468-489.

Kern, D., Moser, R., Hartmann, E., \& Moder, M. (2012). Supply risk management: model development and empirical analy sis. International Journal of Physical Distribution \& Logistics Management, 42(1), 60-82.

Krause, D. (1999). The antecedents of buy ing firms' efforts to improve suppliers. Journal of Operations Management, 17(2), 205-224.

Krause, D., Scannell, T., \& Calantone, R. (2000). A structural analy sis of the effectiveness of buying firms' strategies to improve supplier performance. Decision Sciences, 31(1), 33-55.

Krause, D. R., Vachon, S., \& Klassen, R. D. (2009). Special Topic Forum On Sustainable Supply Chain Management: Introduction And Reflections On The Role Of Purchasing Management. Journal of Supply Chain Management, 45(4), $18-25$.

Kuei, C., Madu, C., \& Lin, C. (2001). The relationship between supply chain quality management practices and organizational performance. International Journal of Quality and Reliability Management, 18(8), 864-872.

Ladhari, R. (2009). A review of twenty years of SERVQUAL research. International Journal of Quality and Service Sciences, l(2), 172-198.

Lambert, D., Cooper, M., \& Pagh, J. (1998). Supply chain management: implementation issues and research opportunities. International Journal of Logistics Management, 8(1), 1-19.

Lambert, D. M., \& Cooper, M. C. (2000). Issues in supply chain management. Industrial Marketing Management, 29(1), 65-83.

Lamming, R. (1993). Beyond Partnership: Strategies for Innovation and Lean supply: London: Prentice-Hall.

Large, R. O., \& König, T. (2009). A gap model of purchasing's internal service quality: Concept, case study and internal survey. Journal of purchasing and supply management, 15(1), 24-32.

Lascelles, D., \& Dale, B. (1989). The buyer-supplier relationship in total quality management. Journal of Purchasing and Materials Management, 25(2), 10-19.

Lorenzo, S., Arcelay, A., Bacigalupe, M., Ignacio, E., Mira, J., Palacio, F., \& Vitaller, J. (1999). An adaptation of the EFQM model to the Spanish health care setting. Paper presented at the 16 th International Conference on Quality in Health care. melbourne, Australia.

Makadok, R. (2001). Toward a synthesis of the resource-based and dynamic-capability views of rent creation. Strategic Management Journal, 22(5), 387-401.

Martínez-López, F. J., Gázquez-Abad, J. C., \& Sousa, C. M. (2013). Structural equation modelling in marketing and business research: Critical issues and practical recommendations. European Journal of Marketing, 47(1/2), 115-152. 
Mcadam, R., \& Leonard, D. (2005). A TQM dynamics perspective on Baldrige and business excellence model comparisons. Total Quality Management \& Business Excellence, 16(6), 771-791.

Mohrw-Jackson, I. (1991). Broadening the market orientation: an added focus on internal customers. Human Resource Management, 30(4), 455-467.

Narasimhan, R., \& Das, A. (1999). An empirical investigation of the contribution of strategic sourcing to manufacturing flexibilities and performance. Decision Sciences, 30(3), 683-718.

Noordewier, T., George, J., \& Nevin, J. (1990). Performance outcomes of purchasing arrangements in industrial buyer-vendor relationships. Journal of Marketing, 54(4), 80-93.

Ojanen, V., Piippo, P., \& Tuominen, M. (2002). Applyingquality award criteria in R\&D project assessment. International Journal of Production Economics, 80(1), 119-128.

Panigy rakis, G. G., \& Theodoridis, P. K. (2009). Internal marketing impact on business performance in a retail context. International Journal of Retail \& Distribution Management, 37(7), 600-628.

Parasuraman, A., Zeithaml, V., \& Berry, L. (1985). A conceptual model of service quality and its implications for future research. The Journal of Marketing, 41-50.

Parasuraman, A., Zeithaml, V. A., \& Berry, L. L. (1988). Servqual. Journal of Retailing, 64(1), 12-40.

Perdomo-Ortiz, J., González-Benito, J., \& Galende, J. (2009). An analy sis of the relationship between total quality management based human resource management practices and innovation. The International Journal of Human Resource Management, 20(5), 1191-1218.

Peteraf, M. A. (1993). The cornerstones of competitive advantage: A resource-based view. Strategic Management Journal, 14(3), 179-191.

PewResearch. (2013). The New Sick Man of Europe: the European Union

French Dispirited; Attitudes Diverge Sharply from Germans. from PewGlobal

Pfau, B., Detzel, D., \& Geller, A. (1991). Satisfy y our internal customers. Journal of Business Strategy, 12(6), 9-13.

Powell, T. (1995). Total quality management as competitive advantage: a review and empirical study. Strategic Management Journal, 16(1), 15-37.

Reihanifard, P., Aminilari, M., Moghadam, R. A., Vahdat, D., \& Mozaffari, S. (2012). Providing a Pattern to Evalute CRM Systems Based on EFQM Model in SMEs. Advanced Materials Research, 463, 1141-1146.

Romano, P., \& Vinelli, A. (2001). Quality management in a supply chain perspective: strategic and operative choices in a textileapparel network. International Journal of Operations \& Production Management, 21(4), 446-460.

Rozemeijer, F., Quintens, L., Wetzels, M., \& Gelderman, C. (2012). Vision 20/20: Preparing today for tomorrow's challenges. Journal of purchasing and supply management, 18(2), 63-67.

Sadeh, E., Arumugam, V. C., \& Malarvizhi, C. (2013). Integration of EFQM framework and quality information sy stems. Total Quality Management \& Business Excellence, 24(1-2), 188-209.

Salvador, F., Forza, C., Rungtusanatham, M., \& Choi, T. (2001). Supply chain interactions and time-related performances. International Journal of Operations and Production Management, 21(4), 461-475.

Samuelsson, P., \& Nilsson, L.-E. (2002). Self-assessment practices in large organisations: experiences from using the EFQM excellence model. International Journal of Quality \& Reliability Management, 19(1), 10-23.

Sánchez, R. M., \& Mora, C. D. (2002). The Integration of Spain in the European Union: Main Industrial Effects: Instituto Universitario Ortega y Gasset.

Sánchez-Rodríguez, C., \& Hemsworth, D. (2005). A structural analy sis of the impact of quality management practices in purchasing on purchasing and business performance. Total Quality Management and Business Excellence, 16(2), 215230.

Sánchez-Rodríguez, C., Hemsworth, D., \& Martínez-Lorente, Á. R. (2004). Quality management practices in purchasing and its effect on purchasing's operational performance and internal customer satisfaction. International Journal of Logistics Research and Applications, 7(4), 325-344.

Sanchez-Rodriguez, C., Martinez-Lorente, A. R., \& Hemsworth, D. (2012). The EFQM excellence model as enabler of eprocurement adoption and the effect on performance. Paper presented at the ECIS, Spain.

Santos-Vijande, M.L., \& Alvarez-Gonzalez, L. I. (2007). TQM and firms performance: An EFQM excellence model research based survey. International Journal of Business Science and Applied Management, 2(2), 21-41.

Saraph, J., Benson, P., \& Schroeder, R. (1989). An instrument for measuring the critical factors of quality management. Decision Sciences, 20(4), 810-829.

Segars, A., \& Grover, V. (1993). Re-examining perceived ease of use and usefulness: A confirmatory factor analy sis. MIS Quarterly, 17(4), 517-525.

Shaw, C. D. (2000). External quality mechanisms for health care: summary of the ExPeRT project on visitatie, accreditation, EFQM and ISO assessment in European Union countries. International journal for quality in health care, 12(3), 169175.

Soriano, D. R. (1999). Total quality management: Apply ing the European model to Spain's urban hotels. The Cornell Hotel and Restaurant Administration Quarterly, 40(1), 54-59.

Stanley, L., \& Wisner, J. (1998). Internal service quality in purchasing: an empirical study. International Journal of Purchasing and Materials Management, 34(3), 50-60. 
Stanley, L., \& Wisner, J. (2001). Service quality along the supply chain: implications for purchasing. Journal of Operations Management, 19(3), 287-306.

Stanley, L., \& Wisner, J. (2002). The determinants of service quality: issues for purchasing. European Journal of Purchasing and Supply Management, 8(2), 97-109.

Stuart, F., \& Mueller, P. (1994). Total quality management and supplier partnerships: a case study. International Journal of Purchasing and Materials Management, 30(1), 14-20.

Svensson, M., \& Klefsjo, B. (2000). Experiences from creating a quality culture for continuous improvements in the Swedish school sector by using self-assessments. Total Quality Management, 11(4-6), 800-807.

Talib, F., Rahman, Z., \& Qureshi, M. (2011). A study of total quality management and supply chain management practices. International Journal of Productivity and Performance Management, 60(3), 268-288.

Tan, K., Kannan, V., Handfield, R., \& Ghosh, S. (1999). Supply chain management: an empirical study of its impact on performance. International Journal of Operations and Production Management, 19(10), 1034-1052.

Tari, J. J., Molina, J. F., \& Castejon, J. L. (2007). The relationship between quality management practices and their effects on quality outcomes. European Journal of Operational Research, 183(2), 483-501.

Tassabehji, R., \& Moorhouse, A. (2008). The changing role of procurement: developing professional effectiveness. Journal of purchasing and supply management, 14(1), 55-68.

Teas, R. (1994). Expectations as a comparison standard in measuring service quality: an assessment of a reassessment. Journal of Marketing, 58(1), 132-139.

Theodorakioglou, Y., Gotzamani, K., \& Tsiolvas, G. (2006). Supplier management and its relationship to buy ers' quality management. Supply Chain Management: An International Journal, 11(2), 148-159.

Trent, R., \& Monczka, R. (1999). Achieving world-class supplier quality. Total Quality Management, 10(6), 927-938.

van Mossel, H.-J., \& van der Valk, W. (2008). Securing customer satisfaction through component service specifications: purchasing maintenance services for social rented housing. Journal of purchasing and supply management, 14(4), 241252.

Vanichchinchai, A., \& Igel, B. (2009). Total quality management and supply chain management: similarities and differences. The TQM Journal, 21(3), 249-260.

Vanichchinchai, A., \& Igel, B. (2011). The impact of total quality management on supply chain management and firm's supply performance. International Journal of Production Research, 49(11), 3405-3424.

Vonderembse, M.,\& Tracey, M. (1999). The impact of supplier selection criteria and supplier involvement on manufacturing performance. The Journal of Supply Chain Management(August), 33-39.

Watts, C., \& Hahn, C. (1993). Supplier development programs: an empirical analy sis. International Journal of Purchasing and Materials Management, 29(2), 11-17.

Wisner, J., \& Stanley, L. (1999). Internal relationships and activities associated with high levels of purchasing service quality. The Journal of Supply Chain Management, 35(3), 25-31.

Wongrassamee, S., Simmons, J., \& Gardiner, P. (2003). Performance measurement tools: the Balanced Scorecard and the EFQM Excellence Model. Measuring Business Excellence, 7(1), 14-29.

Youndt, M., Snell, S., Dean, J., \& Lepak, D. (1996). Human resource management in manufacturing strategy, and firm performance. Academy of Management Journal, 39(4), 839-866.

Young, J., \& Varble, D. (1997). Purchasing's performance as seen by its internal customers: a study in a service organization. International Journal of Purchasing and Materials Management, 33(3), 36-41.

Yu, Q., Qiu, Y., \& Feng, W. (2010). Internal customer orientation and internal supply chain management.

Zink, K. J. (1995). Measuring universities against the European Quality Award criteria. Total Quality Management, 6(5), 547562. 


\section{APPENDIX 1}

Table A1. Quality management key dimensions based on the EFQM model

\begin{tabular}{l|l}
\hline $\begin{array}{c}\text { Quality management } \\
\text { dimensions }\end{array}$ & Description \\
\hline Leadership & $\begin{array}{l}\text { Ability of excellent leaders to develop and facilitate the achievement of the mission and vision by } \\
\text { developing organizational values and sy stems required for sustainable success, as well as } \\
\text { implementing these via their actions and behaviors. }\end{array}$ \\
\hline Strategy & $\begin{array}{l}\text { Captures the organization's efforts to develop a stakeholder-based strategy, taking into account } \\
\text { the characteristics of the market and sector in which the firm operates. Thus, policies, plans, } \\
\text { objectives, and processes are developed and deployed to deliver the strategy. }\end{array}$ \\
\hline People & $\begin{array}{l}\text { Workforce management has to be guided by the principles of training, empowerment of workers, } \\
\text { and teamwork. Adequate plans of personnel recruitment and training have to be implemented and } \\
\text { workers need the necessary skills to participate in the improvement process. }\end{array}$ \\
\hline Resources & $\begin{array}{l}\text { Efforts of excellent organizations to manage external partnerships, suppliers, and internal } \\
\text { resources in order to support policy and strategy and the effective operation of processes. }\end{array}$ \\
\hline Process & $\begin{array}{l}\text { Captures the efforts of excellent organizations to design, manage, and improve processes in order } \\
\text { to fully satisfy and generate increasing value for customers and other stakeholders. }\end{array}$ \\
\hline
\end{tabular}

